\title{
Neutrality of The State Civil Apparatus (ASN) in Indonesian Elections
}

\author{
Muhammad Ruslihardi', Adinda Ramadhani ${ }^{2}$, Siska Wirawati ${ }^{3}$, Tuty Ardian \\ Rahmah $^{4}$, Fajarwaty Kusumawardhani ${ }^{5}$, Sri Roserdevi Nasution ${ }^{6}$, Harcini Harcini ${ }^{7}$ \\ $1,2,3,4,5,6,7$ Public Administration Study Program, Faculty of Administrative Sciences, Universitas Lancang \\ Kuning, Indonesia \\ tutyadrian18@gmail.com
}

\begin{abstract}
The neutrality of ASN has always been a hot topic in various circles. Concern over the alignment of ASN to one of the candidate pairs is the main reason there are three types of politicization of the bureaucracy in Indonesia: First, openly politicization. Second, semi-open politicization, third, closed politicization. By utilizing the votes of civil servants, it is obvious for incumbent candidates with the promise of being given a position or to support their superiors and the mobilization of civil servants during general and regional elections. The politicization of the bureaucracy in Indonesia is still exist, currently politicization can appear from the legislature or from the executive with the aim of perpetuating power. From symptoms ranging from users of state facilities, mobilization of civil servants, compensation for positions, commercialization of positions, recruitment of new civil servants, to removal (depromotion) of regional secretaries. The involvement of the State Civil Apparatus (ASN) in practical politics is obvious because ASN is considered as the easiest way to influence society. The position of ASN is quite strategic and seen in the community, of course, will make it easier for candidates to gain support and have big hopes in the pilkada. The non-neutrality of ASN is certainly in the spotlight amidst the hopes of the community that ASN is able to become a pillar of an example of an honest and fair course of democratization.
\end{abstract}

Keywords: Politization, Bureaucracy, state civil apparatus, regional election

\section{Introduction}

The neutrality of ASN is currently an issue that has received much attention due to the number of violations by ASN employees against the principle of neutrality. These violations occurred, especially before, during, and after the regional election took place in 2015, 2017 and 2018. The issue of ASN neutrality is something that will continue going forward and strategically, owing to the implementation of elections for legislative members and president/vice president in 2019, as well as the fourth wave of simultaneous regional elections in 2020 and the fifth wave in 2024. Meanwhile, ASN employees are required to be neutral in conducting their duties professionally, therefore enforcement of ASN neutrality is pivotal.

Neutrality is one of the important principles in carrying out public service, government and development tasks. Every
ASN employee must be neutral to execute their duties in a professional manner. To enforce the neutrality of ASN, the government has promulgated a number of laws and regulations. However, the level of violations of the neutrality principle among ASN employees is still immens, notably ahead of the election simultaneous. Meanwhile, the non-neutrality of ASN employees can lead to partiality or injustice in policy making and service delivery, which in turn will cause harm to society at large. One essential aspect in enforcing the neutrality of ASN is supervision. An effective ASN supervision system is needed to ensure ASN employees in accomplish their duties comply with the Assessment and Development of the law system and regulations related to ASN neutrality, in order to create a professional and accountable bureaucracy.

Civil Servants are elements of the State Apparatus in executing and 
effectuating government and development in efforts framework to achieve national goals. As for efforts to settle these National goals, it is vital to have civil servants who are full of loyalty and obedience to Pancasila, the 1945 Constitution, the State, and the Government. The role of civil servants is the primary subject in a bureaucracy that has a specific role to be able to carry out state and government tasks.

In this case, the work pattern of Civil Servants is a major element in the creation of professional, fair and equitable services to society. The position of Civil Servants as an element of the state apparatus serves the community and has a loyalty mentality to the state. This implies Civil Servants are required to be neutral from the influence of all groups and political parties and not discriminate against public services.

In relation with the issue of neutrality of Civil Servants, as stated in Law number 43 of 1999 concerning Personnel Principles which strictly regulates the Neutrality of Employees in government as mentioned in article 3 which states that in the position and duties referred to in paragraph (1), Civil Servants must be unbiased from the influence of all political groups and parties and not be discriminatory in providing public services. To ensure the neutrality of Civil Servants as pointed out to in paragraph (2), Civil Servants are prohibited from becoming members and / or administrators of political parties.

Attaining an apolitical bureaucracy in Election is not a mere matter, in Siak Regency for example, in the 2011 regional elections there were many problems in the implementation of elections, one of which was the neutrality of the bureaucracy. The neutrality of the bureaucracy in the Siak Regency Government should be questioned after the phenomenon of many civil servant's partialities within the Siak Regency Government scope to one of the regional head candidate pairs such Syamsuar-Alfedri, the phenomenon of alignment with the pair number 3 is seen in various moments or ceremonial activities in various places. Likely the Rebana Performance in Tualang Sub-district Hall, PGRI Gathering in Sungai Mandau District, Education Quality Seminar and PGRI Anniversary in Tualang and Sungai Apit Districts.

Indeed, what must be emphasized to prohibit Civil Servants from being involved in Direct Regional Election that is in the context of being a participant, both as a candidate for Regional Head and a campaign team supporting the Regional Head. They disposed themselves on one side, it is their's that should be "forbidden". Since they decided to become Civil Servants (PNS) their only side was people interest. They must serve for the people, not for the sake of one or two groups or one or two interests.

Thus, if they are involved as the organizing committee for the Regional Head Election, they are allowed. In the Regional Autonomy government, numerous civil servants abuse their authority. For example, in the implementation of direct regional head elections, abuse of authority often arises. The bureaucracy here is used as a political machine to win the Incumbent.

Democracy is one of the systems used in the Indonesian state. Democracy is the voice of the people. That is, the people determine sovereignty and regulate the direction of the political journey of a country and government. Democracy explains the principle that every human being has the same rights and obligations under government law. Every individual plays a vital role in a democratic system therefore that the concept of human rights is closely related to democratic principles. Democracy is believed to be a system that reflects political mechanisms and is considered capable of assuring a government that is responsive to the wishes of its citizens. As the main condition for the creation of a universal democratic order is general elections. 
General elections are an important means of democracy. In substance, the definition of direct Pilkada what $\mathrm{J}$. Prihatmoko said is less relevant with current conditions. The reason is, the election is still has not opened wide access to society, especially the opportunity to become candidate for regional head, considering that the community does not can nominate a candidate for regional head without having to through political parties.

In addition, the recruitment process for head candidates' areas carried out by political parties tend to limit community opportunity in submission the candidate. For this reason, there are regulations that allow there is an independent candidate to be able to registering for nomination is an open regional head recruitment effort and prioritize the participation of the community. The efforts made by the Election Commission of Pekanbaru in data collection and mapping of suffrage of citizens in the border area of Pekanbaru and Kampar walk is not optimal for a long period of time but has shown improvement on the sustainability of suffrage in the interests of the election (Yandra, 2017). It is not only the definition of a process of real manifestation of people's sovereignty but as an instrument of ongoing social and political change also succession. Election is considered as a concrete form of dominance in people hands and the most tangible of people's participation in state administration. Since with the general election, the community individually has the right to vote to elect a leader or representative of the people.

By virtue of the bureaucrat is not a political apparatus, they should keep away from things that can make them nonneutral. In Law number 5/2014 cites that ASN in conducting its profession must be stand on several principles, namely: basic values; code of ethics and code of conduct; commitment, moral integrity, and responsibility to public services; competencies required in accordance with the field of duty; academic qualification. The basic values in these principles have meanings, including: carrying out duties in a professional and impartial manner; creating a non-discriminatory work environment; accountable for their actions and performance to the public.

\section{Research Method}

The research method in this presentation is literature review. All information and knowledge can be obtained from the website and several journals and documentation related to practical politics. Furthermore, secondary data is obtained through tracking data through mass media and online social media and then interpreted with a theoretical approach

\section{Result and Discussion}

\subsection{ASN Neutrality Violation}

ASN is a public service that should not be interfered with by the flow of practical politics which could cause them no longer professional in their work and non-optimal servants, which is worse, people's interests are distorted and they tend to only assume about their personal affairs. Nevertheless, what happens after observing the field, there are dozens of ASNs that are not neutral in terms of politics. After the author has seen and analyzed the factors that prevent ASN from being neutral, it is quite humane, but whatever it is, ASN is public and may not participate in any political activities.

Types of ASN Neutrality Violations in Political Aspects based on the PANRB Ministry Circular Number B/71/ M.SM.00.00/2017 and KASN Circular Number B-2900/KASN/11/2017, which are as follows:

1. Campaign/social media outreach (posts, comments, shares and likes). This is as Article 11 letter c PP No. 42 of 2004.

2. Involvement in campaign activities. (Article 4 number 15 letter a and 
Article 12 number 9 PP No.53 of 2010).

3. Become a campaign participant using the attributes of the party/civil servant attributes. (Article 4 number 12 letter b PP No.53 of 2010).

4. As campaign participants by mobilizing other civil servants. (Article 4 number 12 letter c PP No.53 of 2010).

5. As a campaign participant with State facilities (Article 4 number 12 letter d PP No.53 of 2010).

6. Making decisions that can benefit/ disadvantage the candidate pairs during the campaign period. (Article 4 number 13 letter a, Article 4 number 15 letter c, and Article 13 PP No.53 of 2010).

7. Using facilities associated with the position in campaign activities. (Article 4 number 15 letter $b$ and Article 13 number 13 Government Regulation No. 53 Year 2010).

In practice, there were three forms of violations committed by civil servants and government officials in elections. First, the abuse of authority they have, including issuing regulations requiring campaigns to subordinates, raising funds for certain political parties, granting business licenses accompanied by demands for support to certain political parties / candidates, using government assistance for campaigns, changing official travel costs, and forcing subordinates to finance campaign for political parties / candidates from the state budget. Second, direct use of state facilities, for example the use of official vehicles, official residences, and government offices and their accessories.
Third, providing other support, such as donation assistance, covert campaigns, attaching political party/ candidate attributes in the office, wearing political party/candidate attributes, attending campaign activities using official attire and accessories, and approving campaign violations using state facilities and unfair treatment/discriminatory for the use of state facilities to political parties/ candidates.

The National Civil Service Agency (BKN) noted that there were 1,005 state civil servants (ASN) who were reported to have violated the neutrality of ASN. Since it is resulted from the reconciliation of data on neutrality violations on Thursday, November 26, 2020 by the Deputy for Supervision and Control of the BKN. Of the thousands who were reported, 727 were recommended to have committed violations. "Up to now, there have been 580 ASNs that have been sanctioned with violations of neutrality by the Agency's Civil Service Officer (PPK). Meanwhile, a total of 147 ASNs have not received follow-up from PPK and 121 others are still being processed by PPK, "as quoted from a written statement from the official BKN website, Monday (30/11/2020).

BKN has also blocked 26 personnel data and unblocked eight personnel data. As for its distribution, blocking is mostly done at central agencies (17 personnel data), Regional Office (Kanreg) IV BKN Makassar (5 personnel data), Kanreg IX BKN Jayapura (2 personnel data), Kanreg III BKN Bandung (1 employment data), and Kanreg XII BKN Pekanbaru (1 employment data). 


\begin{tabular}{clcc}
\hline No & Government Agencies & Total & Investigated \\
\hline 1. & $\begin{array}{l}\text { Purbalingga district } \\
\text { government }\end{array}$ & 56 & 56 \\
2. $\quad \begin{array}{l}\text { Wakatobidistrict } \\
\text { government } \\
\text { South Halmahera } \\
\text { district government }\end{array}$ & 23 & 29 \\
4. $\begin{array}{l}\text { Bimadistrict } \\
\text { government } \\
\text { South Minahasadistrict } \\
\text { government }\end{array}$ & 18 & 23 \\
\hline
\end{tabular}

Table 2

Top 5 Neutrality Customer Data per Regional Office

\begin{tabular}{ccccc}
\hline No & Regional Office & Ciry & Total & Investigated \\
\hline 1. & $\begin{array}{c}\text { Regional Office } \\
\text { IV BKN }\end{array}$ & Makassar & 180 & 161 \\
2. & $\begin{array}{c}\text { Regional Office X } \\
\text { BKN }\end{array}$ & Denpasar & 103 & 101 \\
3. & $\begin{array}{c}\text { Regional Office } \\
\text { XI BKN }\end{array}$ & Manado & 89 & 85 \\
4. & $\begin{array}{c}\text { Regional Office I } \\
\text { BKN }\end{array}$ & Yogyakarta & 82 & 82 \\
5. & $\begin{array}{c}\text { Regional Office } \\
\text { XII BKN }\end{array}$ & Pekanbaru & 75 & 72 \\
\hline
\end{tabular}

Table 3

Top 5 Neutrality Violation Data per Types

No Violation types $\quad$ Total Investigated

Providing support to regional head/deputy regional head candidates. By carrying out activities that lead to taking sides with candidate pairs who participate in the election before, during and after the campaign period, including meetings, invitations, appeals, appeals, or giving goods to civil servants within their work unit , family and community members (article 4 number 15 letter d)

Involving in campaign activities to support candidates

2. for Regional Head / Deputy regional head (article 4 point 15 letter a)

3. Run for regional head 
4. Take sides with the influence they have

5. Using facilities associated with the position in campaign activities. (Article 4 point 15 letter b)

\subsection{Causes of ASN Non-Neutrality}

According to survey results in the field of study and development of the KASN system in 2018, there were several factors that caused violations of ASN neutrality. These factors include: the imposition of sanctions is still feeble, the non-neutrality of ASN which is still considered normal, lack of integrity of ASN to be neutral, the intervention from the leadership, lack of understanding of regulations regarding the neutrality of ASN, the motive to get or maintain a position, material, or project as well as kinship with candidates (menpan.go.id, 10 August 2020). In addition, according to the Executive Director of the Association for Elections and Democracy (Perludem), Titi Anggraini, the neutrality of ASN will get worse if it is added to the issue of kinship politics in political parties in each region. Therefore, it is necessary to make a regulation that reforms political party institutions that they no longer prioritize kinship political systems in political recruitment, as well as the need to revise general election regulations (validnews.id, 10 August 2020).

Meanwhile, Commission II of the House of Representatives of the Republic of Indonesia proposed that the position of ASN is equivalent to that of the TNI/Polri in the simultaneous regional elections, namely that ASN voting rights are proposed to be eliminated. As stated in the Deputy Chairman of Commission II of the Indonesian Parliament, Saan Mustopa, ASN is often used by incumbent regional head candidates who take advantage of ASN position to gain votes or support from the bureaucracy so the neutrality during the elections in ASN is difficult to materialize (m.medcom.id, 31 August 2020).

\subsection{ASN Sanctions that Violate the Neutrality of the Regional Election}

A total of 362 State Civil Servants (ASN) who were deemed to have violated neutrality in the 2020 simultaneous regional elections received sanctions on November 5, 2020. These sanctions were given by the Civil Service Officer (PPK) in accordance with the provisions of the Joint Decree (SKB) of the Head of the State Civil Service Agency (BKN) Minister for Administrative Reform and Bureaucratic Reform (PAN RB), Minister of Home Affairs, Chairperson of the State Civil Apparatus Commission (KASN) and Chairman of the Election Supervisory Agency (Bawaslu) concerning Guidelines for Monitoring the Neutrality of State Civil Servants in Organizing Concurrent Regional Head Elections in 2020. "Neutrality is a common concern that we must continue to maintain as a form of our consistency in implementing the SKB", said Deputy for Supervision and Control of BKN Otok Kuswandaru in a written statement received by Kompas.com, Thursday (12/10/2020). Meanwhile, Director of Supervision and Control IV Bambang Hari Samastostated that ASN neutrality is apivotal prerequisite for the effective implementation of ASN functions. "Namely ASN as Policy Executor, Public Servant and the glue of the Unitary State of the Republic of Indonesia (NKRI)," he said. Bambang emphasized that there should be no perception that there is no problem if civil servants violate neutrality. Imposing sanctions is considered an effective way so that violations of neutrality by civil servants can be minimized.

Other data on ASN neutrality violators stated that as many as 827 ASNs had been 
reported as violating neutrality. In addition, as many as 606 ASNs who violated them have received recommendations from KASN. Meanwhile, the other 72 ASNs have not been followed up by PPK by imposing sanctions and blocked employment data.

Meanwhile, the Government of the Republic of Indonesia through the Ministry of Administrative and Bureaucratic Reform (Kemenpan RB) emphasizes the importance of the State Civil Service (ASN) to maintain neutrality during the political year (2018-2019). Therefore, every ASN violating the ASN code of ethics during that period must be prepared to bear sanctions. Civil servants who do not implement these provisions will be subject to disciplinary sanctions. In the letter stipulated on December 27, 2017, it was stated that in accordance with the Government Regulation of the Republic of Indonesia Number 53 of 2010 concerning Discipline of Civil Servants, moderate to severe disciplinary penalties will be imposed. The sanctions are in the form of postponement of periodic salary increases for 1 year, then postponement of rank for 1 year, and demotion of one lower level for 1 year.

Whereas for severe discipline, sanctions can be imposed in the form of a demotion of a lower level for three years, other than that transfer can be imposed in the context of a lower level demotion, then release from office or dismissal with respect not at his own request as a civil servant.

Table 4

\section{Survey Results for System Assessment and Development, KASN 2018 The cause of} violation of ASN neutrality

\begin{aligned} & \hline $43,4 \% \begin{array}{l}\text { There is a motive for getting } \\ \text { / maintaining position / } \\ \text { material / project } \\ \text { There is a kinship with the } \\ \text { candidate } \\ \text { Lack of understanding of } \\ \text { rules / regulations regarding } \\ \text { the neutrality of ASN } \\ \text { There is intervention / } \\ \text { pressure from leaders / } \\ \text { superiors. }\end{array} \\ & 7,7 \%$ Lack of ASN integrity to be \\ & neutral \\ & ASN non-neutrality is seen \\ & as commonplace \\ & Weak sanction \\ & No answer \end{aligned}

Source: Survey Results for System Assessment and Development, KASN 2018

\section{Conclusion}

The rise in cases of violations of ASN neutrality shows that the politicization of the bureaucracy is still closely related to the practice of government administration, especially ahead of the General Election and Pilkada. The position of ASN as a bureaucratic engine can turn into a political machine for the authorities. This of course is inseparable from the regulatory system that places regional heads as PPK which has a major influence on the behavior and position of ASN. This can also have an 
impact on the professionalism of ASN's work in government administration.

As for the Inhibiting Factors of the Effectiveness of Enforcement of ASN Neutrality :

1. Legal substance, in Law 7 of 2017 article 280, article 282 and article 283, there are legal loopholes that can weaken the prosecution of ASN Neutrality offenders.

2. Legal Structure, KASN Recommendations are sometimes ignored by Civil Service Officers (PPK), KASN structures and personnel are limited because they are not in the area, Supervision of the inspectorate supervising ASN employees is still weak resulting in violations of ASN neutrality not being dealt with firmly.

3. The legal culture of the community who is reluctant to report cases of violations of ASN Neutrality because they feel that they will damage relationships and there is a feeling of embarrassment, as well as perceiving violators of ASN neutrality is commonplace.

\section{References}

Asbudi, A. (2020). PENCEGAHAN DAN PENINDAKAN PELANGGARAN NETRALITAS APARATUR SIPIL NEGARA (ASN) OLEH BAWASLU KOTA PALOPO PADA PEMILU 2019. Journal I La Galigo Public Administration Journal, 3(2), 9-17.
DewiSendhikasari,

D.

(2020).

NETRALITAS APARATUR SIPIL NEGARA DALAM PILKADA. Pusat Penelitian Badan Keahlian DPR RI.Gd. Nusantara I Lt. 2 Jl. Jend. Gatot Subroto Jakarta Pusat 10270.

Wulandari, W. (2017). "Netralitas Aparatur Sipil Negara (ASN) dalam Pemilihan Umum Kepala Daerah Serentak". Jurnal Naskah Publikasi, 1-13.

Yandra, A. (2017). FISIBILITAS PILKADA SERENTAK TAHAP II KOTA PEKANBARU PASCA PERMENDAGRI NO 18 TAHUN 2015. Jurnal Niara, Vol 9, 62-74.

Yandra, A. (2017). PENYELAMATAN HAK PILIH WARGA PERBATASAN JELANG PILKADA. Jurnal Kajian Politik dan Masalah Pembangunan, Vol 13 No.1 , 1943-1952.Zudi, M., Hidayat, A., \& Hardjanto, U. S. (2012). Netralitas Pegawai Negeri Sipil Dalam Pemilihan Kepala Daerah. Diponegoro Law Journal, 1(4).

http://berkas.dpr.go.id/puslit/files/info_sing kat/Info\%20Singkat-XII-17-I-P3DISeptember-2020-207.pdf

https://detikdispen.bkn.go.id/home/index/20 20.

http://indonesiabaik.id/infografis/sanksibagi-asn-tak-

netral\#: :text=Sanksinya\%20berup a\%20penundaan\%20kenaikan\%20g aji,lebih\%20rendah\%20selama\%20 $1 \% 20 t a h u n$. 